\title{
Melhoramentos, reaparelhamentos e modernização dos portos brasileiros: a longa e constante espera ${ }^{1}$
}

\author{
Alcides Goularti Filho ${ }^{2}$
}

\section{Resumo}

O objetivo deste artigo é discutir a trajetória do sistema portuário brasileiro de 1910 (criação da Inspetoria Federal de Portos, Rios e Canais) a 2001 (criação da Agência Nacional de Transportes Aquaviários) destacando as constantes iniciativas e tentativas de melhoramento, reaparelhamento e modernização dos portos. Além da introdução e da conclusão, o texto está dividido em três períodos: a) início da centralização e da formação de um sistema nacional portuário 1910-1934; b) centralização e planejamento: reaparelhamento e consolidação de um sistema portuário nacional 1934-1990; e c) a modernização e privatização dos portos 1990-2001. Ao longo de cada período são discutidos a criação dos diversos órgãos responsáveis pelos portos, a gestão do sistema, as leis e decretos específicos para os portos e os planos portuários nacionais.

Palavras-chave: Portos - Planejamento; Administração; Portos - Política governamental - Brasil.

\begin{abstract}
Improvements, equipment and modernization of the Brazilian ports: the long and constant wait

The objective of this article is to argue the formation of the Brazilian port system of 1910 (creation of the Federal Inspectorial of the Ports, Rivers and Canals) the 2001 (creation of the Aquatic Way Transport National Agency) detaching the constants initiatives and attempts of improvement, equipment and modernization of the ports. Beyond the introduction and the conclusion, the text is divided in three periods: the beginning of the centralization and the formation of a port national system 1910-1934; b) centralization and planning: equipment and consolidation of a national port system 1934-1990; e) the modernization and privatization of ports 1990-2001. The long one of each period is argued the creation of the diverse responsible agencies for the specific ports, laws and decrees and national ports plans.
\end{abstract}

Key words: System port; Planning; Administration port.

JEL N960, N760, N660, R500.

\section{Introdução}

O surgimento dos diversos portos no litoral brasileiro está relacionado com a ocupação e o povoamento do território. O mar sempre foi um caminho

(1) Trabalho recebido em março de 2006 e aprovado em abril de 2007. Pesquisa financiada pelo Conselho Nacional de Desenvolvimento Científico e Tecnológico (CNPq) e Fundação de Apoio à Pesquisa Científica e Tecnológica do Estado de Santa Catarina (Fapesc).

(2) Doutor em Economia pelo Instituto de Economia da Universidade Estadual de Campinas (IE/Unicamp). Professor do Departamento de Economia da Universidade do Extremo Sul Catarinense (Unesc),

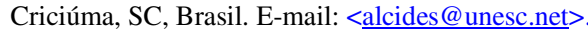

Economia e Sociedade, Campinas, v. 16, n. 3 (31), p. 455-489, dez. 2007. 
natural e um elo entre a colônia e a Coroa, e entre as várias vilas fundadas ao longo da costa brasileira. Pelo mar, fazia-se a guarda do território, chegavam e saíam mercadorias e pessoas. Os portos surgiram como consequiência desse movimento de pessoas, mercadorias e armas. Durante todo o período colonial, os portos eram pequenos trapiches e ancoradouros naturais que serviam como plataforma de embarque e desembarque. Recife, Salvador e Rio de Janeiro, por serem as vilas mais importantes, eram também os portos que tinham maior fluxo de mercadorias e pessoas. Em função do Pacto Colonial e das dificuldades técnicas e naturais de navegação entre portos da costa brasileira, o maior movimento nos portos era sempre em relação à Coroa: exportando gêneros tropicais e metais preciosos e importando produtos manufaturados. Da África eram trazidos os negros para serem escravizados.

No interior da colônia, as vias de comunicação eram basicamente duas: navegação fluvial (canoagem) e caminhos. A navegação fluvial foi obra do bandeirismo, das monções que seguiram principalmente para o centro-oeste da colônia. Os caminhos, traçados primeiramente pelos bandeirantes, foram obras dos tropeiros, que faziam a ligação da parte meridional da colônia com as feiras paulistas (Prado Júnior, 1996). Os caminhos das tropas e navegação fluvial alargaram o território da colônia para além do Tratado de Tordesilhas, garantindo, em boa medida, o atual contorno das fronteiras brasileiras, e deram uma coesão aos esparsos núcleos de povoamento. Segundo Roberto Simonsen (1977, p. 437):

Aos atalhos trilhados pelos bandeirantes no ciclo da caça aos índios, sucedeu a construção de caminhos para servir às zonas de mineração. Não surgisse esta e a ocupação dos sertões, na escala em que foi feita, não se teria efetuado - por necessária à exploração agrícola e extrativa da colônia. Era, porém, a rede fluvial o grande meio preferido para o tráfego - tantas as insuficiências e a primitividade dessas estradas e as dificuldades de sua conservação.

Essas duas vias de comunicação foram as mais utilizadas durante todo o período colonial e o início do Império. Para Odilon Nogueira de Matos (1995, p. 42):

Uma carta das vias de comunicações do Brasil, ao iniciar o Império, poucas modificações apresentaria com relação aos últimos tempos coloniais. É bem verdade que a grande expansão sertanista do século XVIII, mineradora ou pastoril, levará o povoamento às extensas áreas do interior, assegurando para Portugal, e conseqüentemente para o Brasil, a posse de tão dilatadas regiões e tornando o mapa do Brasil, resultante dos tratados de Madri e Santo Idelfonso, praticamente igual ao de hoje.

Com o advento do barco a vapor passou-se a melhor utilizar os rios como via de comunicação. Podemos afirmar que, entre 1840 e 1870, predominou no Brasil a navegação fluvial a vapor, com a constituição de várias companhias regionais e nacionais de navegação. A navegação surge, em detrimento dos 
caminhos já traçados pelos tropeiros os quais não eram mais prioridades para o governo imperial, que apostava na navegação fluvial. A navegação suplantou os caminhos. O período de 1870 a 1940 foi a era ferroviária no Brasil. As ferrovias, como símbolo da modernidade e da velocidade, foram construídas sem ser acompanhadas dos devidos melhoramentos na navegação fluvial. A ferrovia suplantou a navegação. Entre 1940 e 1980, vimos florescer no Brasil o sistema rodoviário. As rodovias chegaram em todas as regiões do país, integrando todo o território nacional. Em 1930, o país tinha 36 mil quilômetros de ferrovias, atualmente são aproximadamente 30 mil quilômetros. As rodovias foram construídas e pavimentadas sem serem acompanhadas de melhoramentos nas ferrovias. Novamente, uma suplantou a outra.

Com relação aos portos, durante o período colonial, os portos brasileiros eram de responsabilidade das Câmaras Municipais. Ainda nesse período, foi editado o Decreto de 13 de julho de 1820, que declarou de competência da Repartição da Marinha todos os portos espalhados pela costa brasileira (Brasil, 1889). Com a Independência, em 1822, e com uma nova organização administrativa, os portos passaram a ser de responsabilidade da Intendência dos Arsenais da Marinha, dentro do Ministério da Marinha. Em 1845, foi criada a Capitania dos Portos, que se tornou responsável pelo policiamento e melhoramento dos portos. Após muita insistência do Ministério da Marinha, a responsabilidade sobre os portos passou, em 1873, para o Ministério da Agricultura, Comércio e Obras Públicas, que dividiu o litoral em seis distritos e, em 1890, criou as Inspetorias de Distritos dos Portos Marítimos. Com a divisão do Ministério da Agricultura, os portos ficaram com o Ministério da Viação e Obras Públicas.

A primeira norma jurídica destinada aos portos brasileiros, após o Decreto de 1820, foi o Decreto 447 de 1846 que aprovou o Regulamento da Capitania dos Portos. Em 1869 foi editado o Decreto 1.746, que autorizava a concessão dos portos por 90 anos à iniciativa privada e dava garantia de juros de $12 \%$ ao ano. Em 1886, a Lei 3.314 reduziu o prazo para 70 anos e a garantia de juros para $6 \%$ ao ano. Em 1903, foi editado o Decreto 4.859, em que o governo ficava responsável pela obras dos portos e em seguida poderia conceder à iniciativa privada por 10 anos. No Decreto-Lei 6.368, de 1907, ficou aprovada a criação de uma repartição que deveria ficar responsável pela centralização das obras de melhoramento, conservação e administração dos portos.

O objetivo deste texto é percorrer os caminhos das dificuldades e dos avanços do sistema portuário brasileiro a partir da dinâmica da economia brasileira no século XX. Além desta introdução, inicialmente, será discutida a organização do sistema portuário nacional durante as primeiras décadas do século $\mathrm{XX}$, que vai do período de 1910 a 1934 quando o problema portuário começou a ser 
nacionalizado, resultando na criação da Inspetoria Federal de Portos, Rios e Canais. O segundo período estudado é de 1934 a 1990, quando entrou em marcha o longo processo de industrialização e de integração nacional comandado pelo Estado, quando há o planejamento e a centralização das tomadas de decisões das políticas portuárias. O último período analisado é pós-1990, quando é extinta a Portobrás, desarticulando o sistema institucional portuário, iniciando o processo de privatização das operações portuárias. Também é feita uma reflexão sobre a criação dos diversos órgãos federais responsáveis pela gestão do sistema, os regimes jurídicos e os planos portuários. Na conclusão, como tentativa de síntese, será apresentada uma análise sobre o movimento lento de mudanças dos portos brasileiros.

\section{De um sistema fragmentado ao início da centralização das políticas portuárias 1910-1934}

A Primeira República herdou um sistema portuário fragmentado e em precárias condições com portos e trapiches espalhados ao longo da costa sem condições de suportar o aumento do fluxo de carga. Desde o Porto de Manaus, passando por Recife, Salvador, Rio de Janeiro e chegando até os pequenos trapiches no Sul do Império, todos necessitavam de melhoramentos, segurança e recursos humanos.

No início da República, o complexo cafeeiro estava em franca expansão, principalmente com a construção das ferrovias que cortavam todo o interior paulista ligando ao Porto de Santos. A cidade de São Paulo estava se urbanizando rapidamente e a chegada de mais e novos imigrantes mudava o cotidiano na capital paulista e nas fazendas de café do interior. No Norte do país, a borracha era o grande produto de exportação que formava um grande complexo extrativista integrando a região à economia mundial. No Nordeste, apesar da longa e lenta decadência da economia açucareira, a mecanização de alguns engenhos ensaiava um novo impulso econômico para a região. No Maranhão, ainda resistia a lavoura de algodão e, no Sul da Bahia, o cacau estava se expandindo. No Brasil meridional, destacavam-se a pecuária de corte no Sul do Rio Grande do Sul e a erva-mate no Norte de Santa Catarina e Sul do Paraná (Cano, 1990). Esse era o movimento geral da economia brasileira que tinha uma estreita ligação com o desenvolvimento dos portos brasileiros: a borracha em relação ao Porto de Manaus, a cana-de-açúcar em relação ao Porto de Recife, o algodão em relação ao Porto de Maranhão, o cacau em relação ao Porto de Salvador, café em relação ao Porto de Santos, a erva-mate em relação aos Portos de Paranaguá e São Francisco do Sul e o charque em relação ao Porto de Rio Grande. Ao mesmo tempo em que se expandiam as exportações também cresciam as importações. Segundo Cardoso de Mello (1988), foi dos poros da acumulação desta economia mercantil agrária e 
exportadora e da metamorfose do capital mercantil em industrial que nasceu e se consolidou o capital industrial.

A política de transportes da jovem República era a mesma do velho Império: a prioridade eram as ferrovias, num segundo plano vinha a navegação fluvial e marítima a vapor. O boom ferroviário inglês foi no segundo quartel do século XIX, o norte-americano após a Guerra Civil e o alemão no último quartel do século XIX. Portanto, dar ênfase às ferrovias no Brasil durante o Segundo Reinado e a Primeira República estava dentro da tendência mundial da rápida expansão dos caminhos de ferro. A questão, a saber, era: por que os portos continuaram relegados a planos inferiores mesmo ainda com a utilização em larga escala da navegação marítima a vapor?

Durante o período de 1910 a 1934, que foi caracterizado pelo início da nacionalização do problema portuário com a centralização das tomadas de decisões, podem-se destacar dois avanços para os portos: a criação da Inspetoria Federal dos Portos, Rios e Canais em 1910 e a aprovação do Regulamento dos Portos Organizados em 1922. Quando da aprovação do Regulamento, mesmo tendo como móvel da acumulação o capital mercantil agrário e exportador, a economia brasileira passava por um processo de diversificação econômica. Tais condições concretas rebatiam na já estrutura portuária deficiente, que contribuía para agravar ainda mais a situação precária dos portos.

\subsection{Inspetoria Federal de Portos, Rios e Canais}

A IFPRC (Inspetoria Federal de Portos, Rios e Canais), prevista no Decreto 6.368 de 14 de fevereiro de 1907 e criada pela Lei 2.356 de 31 de dezembro de 1910, nasceu no bojo de um movimento maior que foi a criação de vários órgãos federais como a Inspetoria Federal de Viação Marinha, Inspetoria Geral de Iluminação, Inspetoria Federal das Estradas, Inspetoria de Obras Contra a Seca e Repartição Geral dos Telégrafos (Brasil, 1916). A ossatura material do Estado estava ganhando mais consistência iniciando uma trajetória de centralização das ações estatais. Num período em que o federalismo orientava os acordos políticos e os complexos agro-regionais exportadores comandavam as economias locais.

Antes da criação da Inspetoria, o Decreto 4.859 de 1903 já havia previsto a constituição da Caixa Especial dos Portos, cujos recursos eram provenientes de uma taxa de $2 \%$ cobrada sobre as importações e $1 \%$ sobre as exportações, tal como previsto na Lei 3.314 de 1886. Os recursos da Caixa deveriam ser depositados numa conta no Tesouro Nacional que seria destinada ao pagamento de despesas com a fiscalização, os estudos, as obras de melhoramentos, os juros e as amortizações dos empréstimos (Lisboa, 1922). Quanto maior era o fluxo de 
mercadorias, maior era a capacidade de arrecadação, o que possibilitava a expansão das instalações portuárias, portanto é fácil entender por que somente Manaus, Rio de Janeiro e Santos foram os portos que receberam vultosos investimentos. A Lei 3.314, de 1886, que dava garantia de juros de $6 \%$ ao ano, tinha o propósito de beneficiar todos os portos, mas somente o porto do café e o porto da borracha foram os mais atrativos para o capital privado. Na primeira década do novo século, apesar de falta de recursos, foram sendo implementados pequenos melhoramentos e conservações nos principais portos da República.

Em 1912, a situação administrativa e os trabalhos de conservação e melhoramento dos principais portos eram as seguintes: sob regime de concessão, Manaus, Belém, Vitória, Santos e Rio Grande; por conta da União, Recife e Rio de Janeiro; por administração da comissão do Ministério, Natal, Cabedelo e Florianópolis; projetos aprovados para melhoramentos e abertos para concorrência os Portos de Jaraguá e Paranaguá; elaboração de estudo, São Luiz e Amarração (Piauí) (Brasil, 1912). Com a criação da Inspetoria e da Caixa Especial, foram ampliados os serviços nos portos, porém continuavam muito aquém das necessidades exigidas pelo fluxo de mercadorias.

Os adventos da Primeira Guerra Mundial trouxeram mais dificuldades para a nascente indústria nacional, que se viu na obrigação de melhor utilizar a capacidade instalada e a disponibilidade dos recursos minerais. O Estado teve que cancelar obras e suspender contratos. Para os portos brasileiros houve restrições de despesas com os diferentes serviços, o "adiamento de trabalhos menos urgentes feitos por administração e a suspensão temporária de algumas obras de portos contratados" (Brasil, 1917, p. 275). Em 1916, com apenas cinco anos de existência, foi executada a primeira reforma administrativa na Inspetoria com o intuito de reduzir o número de funcionários, considerando os estritamente necessários aos serviços e reorganização da fiscalização dos portos e das comissões administrativas de estudos e obras (Brasil, 1917). Nesse mesmo ano, por uma determinação do Ministério da Fazenda (Lei 4.783/1923), foram suspensos os saldos e extinta a Caixa Especial dos Portos.

Com base na lei da concessão de 1869 e no decreto do contrato por administração de 1903, foram criadas várias companhias estrangeiras com a participação de empresários brasileiros, que tinham como objetivo construir e administrar os principais portos brasileiros. Mesmo com as concessões repassadas às companhias privadas (com exceção do Porto de Manaus), umas não cumpriram os prazos, outras os contratos não foram renovados e outras foram entregues aos governos estaduais. As principais companhias portuárias eram as seguintes:

- Porto de Manaus: Manaos Harbour Company Limited

- Porto de Belém: Port of Pará 
- Porto de Recife: Société de Construction du Port de Pernambuco

- Porto do Rio de Janeiro: Compagnie du Port de Rio de Janeiro

- Porto do Rio Grande: Compagnie Française du Port de Rio Grande do Sul (Brasil, 1917)

- Porto de Salvador: Société de Construction du Port de Bahia

- Portos de Amarração, Fortaleza e Natal: North Griffiths

- Porto da Paraíba: C. H. Walker \& Co. Nelle (Brasil, 1923).

Com a transferência da concessão dos portos para os estados (Lei 652/1899), a União transferia responsabilidades, mas isso não significou a sua isenção completa, pois os recursos necessários aos melhoramentos e à conservação ainda dependiam dos cofres da União.

Quadro 1

Concessões dos portos feitas aos governos estaduais

\begin{tabular}{|l|c|c|}
\hline \multicolumn{1}{|c|}{ Porto } & Decreto & Ano \\
\hline Porto de Paranaguá (Paraná) & 12.477 & 1917 \\
\hline Porto de São Luiz (Maranhão) & 13.270 & 1918 \\
\hline Porto de Recife (Pernambuco) & 14.531 & 1920 \\
\hline Porto de São Francisco do Sul (Santa Catarina) & 15.203 & 1921 \\
\hline Porto de Vitória (Espírito Santo) & 16.739 & 1924 \\
\hline Porto de Niterói (Rio de Janeiro) & 16.962 & 1925 \\
\hline Porto de São Sebastião (São Paulo) & 17.957 & 1927 \\
\hline Porto de Pelotas (Rio Grande do Sul) & 18.487 & 1928 \\
\hline Porto de Amarração (Piauí) & 18.816 & 1929 \\
\hline Porto de Aracaju (Sergipe) & 18.946 & 1929 \\
\hline Porto de Cabedelo (Paraíba) & 20.183 & 1931 \\
\hline Porto de Maceió (Alagoas) & 23.459 & 1933 \\
\hline Porto de Fortaleza (Ceará) & 23.606 & 1933 \\
\hline
\end{tabular}

Fonte: Decretos federais de autorização, concessão, rescisão e encampação dos respectivos portos.

O novo regime portuário implantado com o Decreto 4.859, de 8 de junho de 1903, apresentava avanços, mas muito aquém das necessidades. O governo passou a assumir a responsabilidade financeira das obras, contratando por empreitada ou por administração e quando ficavam prontas as obras, o porto poderia ser arrendado por um prazo de 10 anos. Muitas obras começavam e eram paralisadas, o que custava "aviltados sacrifícios" para o governo (Brasil, 1903, p. 10,). A espera continuava. Mesmo assim, entre concessões, encampações e cancelamentos de contratos sempre foram feitos melhoramentos e conservações nos principais portos da República. O problema era que os melhoramentos não acompanhavam o crescente fluxo de mercadorias. No início dos anos 1920, os Portos de Santos e Rio de Janeiro ainda continuavam sendo os mais equipados e o de Manaus, que recebeu vultosos investimentos após a concessão, em 1902, 
começava a sofrer com a rápida decadência da economia da borracha. Como esperar que capitais nacionais investissem nos portos se nem ao menos havia uma base industrial sólida e um sistema financeiro capaz de financiar investimentos de longo prazo? Faltava para a indústria nacional acumulação vertical e capital financeiro. Nos anos 1920, a economia brasileira passou por uma diversificação produtiva com o surgimento de setores industriais mais complexos e dinâmicos como cimento, ferro, aço, metal-mecânico, papel e celulose, produtos de borracha, químicos e frigoríficos, o que significava mais importações (Suzigan, 2000, p. 120). Ao mesmo tempo, houve novos surtos na produção de café e decadência na produção de borracha. Esse movimento rebatia nos portos, via exportações ou importações. Não era mais possível esperar da iniciativa privada novos investimentos.

Diante desse quadro, o engenheiro Francisco Bicalho sugeriu ao governo federal que encampasse e resgatasse as concessões dos portos. Para Bicalho (Brasil, 1920, p. 189):

O serviço de portos não deve ser uma fonte de rendas para o Estado, e sim um meio de fomentar outras rendas indiretas de muito maior monta. [...] o governo deve tomar a si a construção dos portos, aparelhá-los convenientemente, e depois arrendá-los por prazo nunca superior a dez anos.

Segundo Bicalho, as concessões feitas aos estados brasileiros deveriam ser revertidas, pois muitos desses estados não tinham recursos suficientes para o custeio das obras de melhoramento e, quando os tinham, esses recursos provinham de hipoteca das rendas e dos proventos futuros. Outro sério problema, apontava Bicalho, eram as legislações portuárias:

É incoerente e desconexa, pois foram sendo resolvidos os mais variados casos concretos, à proporção que vinham aparecendo nos contratos. Falta-lhes assim uma orientação geral, a unidade de vistas necessária em assunto tão importante (Brasil, 1920, p. 191).

Em 1918 e 1919 foi proposta uma nova reforma administrativa na Inspetoria, a segunda em seis anos. Uma das propostas da reforma seria a formação de dois núcleos de pessoal e de material de dragagem situados no Norte e no Sul do país.

\subsection{Regulamento dos portos organizados}

Em 1922, foi aprovado o Regulamento de Portos Organizados. O novo Regulamento da Inspetoria tinha como objetivo reunir toda a equipe técnica e administrativa que antes estava distribuída em várias comissões e fiscalizações nos diversos estados. A intenção era criar uma harmonia entre a administração pública nos portos com as capitanias, alfândegas e fiscalizações, cada uma com funções distintas (Brasil, 1924). 
De acordo com o regulamento, era considerado porto organizado:

Art. $1^{\circ}$. Nos portos providos de instalações modernas de cais, de molhes e obras congêneres, serviços de dragagem e outros necessários ao tráfego dos navios [...].

Art. $3^{\circ}$. Serão consideradas instalações do porto todas as obras ou vias naturais de acesso ao mesmo porto, bem como os aparelhamentos necessários ao seu movimento marítimo comercial.

Art. $7^{\circ}$. Para os efeitos do presente regulamento serão considerados como "Empresas de Portos" todas as empresas, companhias ou sindicatos, que tenham a seu cargo a exploração dos serviços das instalações do porto, e consideradas delegadas imediatas da Repartição de Fiscalização de Portos (Brasil, 1924, p. 553$554)$.

Foram considerados portos organizados: Manaus, Belém, Recife, Salvador, Vitória, Rio de Janeiro, Santos e Rio Grande (Brasil, 1928). Com a criação dos portos organizados, ficou estabelecida uma hierarquia portuária no Brasil, em que cada porto principal estava margeado por diversos pequenos portos tributários.

Mais do que um período de diversificação da base industrial, os anos 1920 representaram para o Brasil um período de transição. Transição de uma economia baseada num padrão de acumulação agrário-mercantil exportador, cujo maior indutor da renda era o complexo cafeeiro, para um novo padrão de acumulação baseado no capital industrial. Os anos 1920 engendraram as condições necessárias para a ruptura promovida pela Revolução de 1930. No ponto de vista externo, a ruptura do padrão-ouro e a instabilidade nas economias européias forçavam um novo rearranjo nas relações internacionais, dando início a uma ampliação da margem de manobra para as economias periféricas manipularem suas políticas econômicas domésticas (Aureliano, 1981).

As transformações na base econômica nos anos 1920 aos poucos iam forjando no Brasil uma nova composição política com a presença de uma burguesia industrial e urbana, que rapidamente ia alterando a estrutura política e jurídica do Estado. A autonomia federalista e o poder das oligarquias regionais estavam se tornando um entrave no livre desenvolvimento das forças produtivas industriais. Essas oligarquias regionais contribuíam para liberar as forças produtivas agrárias, mas a industrial dependia mais de uma burguesia industrial e do banqueiro. Todo esse movimento desembocou na Revolução de 1930. Segundo Draibe (1985, p. 60), a Revolução de 1930 inaugurou uma nova etapa no Brasil:

[Uma] etapa decisiva do processo de constituição do Estado brasileiro. A quebra das "autonomias" estaduais que amparavam os "pólos oligárquicos" resultou numa crescente descentralização do poder: concentrando-se progressivamente no executivo federal os comandos sobre as políticas econômica e social. 
Mesmo continuando como República Federativa, as unidades subnacionais passaram a ser mais subordinadas ao Executivo Federal, que centralizava as decisões mais importantes. Segue Draibe (1985, p. 60):

Esse movimento de centralização e concentração do poder, sob os múltiplos aspectos em que se expressou, conduzirá o Estado brasileiro a uma forma mais avançada de Estado Nacional, capitalista e burguês.

$\mathrm{Na}$ verdade, a centralização e a concentração do poder não foram implantadas "numa só tacada", foi um movimento que vinha sendo esboçado nos anos anteriores. As mudanças na base concreta iam forçando transformações. Podemos observar esse movimento rumo à centralização dentro da Inspetoria de Portos, Rios e Canais, criada em 1910 e que passou por duas reformas administrativas, uma, em 1916, e outra, em 1921. Ambas as reformas foram no sentido de centralizar ainda mais as decisões e qualificar o pessoal técnico. Havia um choque de interesses entre a Inspetoria, que fazia uma leitura mais do todo, e as Comissões e as Fiscalizações Estaduais, que pensavam mais nos interesses dos portos regionais e locais.

Em 1930, o inspetor Hidelbrando Góes publicou um livro/relatório que expressou bem o espírito de mudança da época, pautado numa maior atuação do Estado na economia e na centralização das tomadas de decisões. Segundo Góes, o governo federal deveria abandonar a velha política de pensar o melhoramento dos portos, que era fragmentada e desarticulada, para pensar uma nova política centralizada e hierarquizada. Para Góes (1930, p. 4):

O desenvolvimento do nosso sistema portuário não obedece a nenhum programa antecipadamente estudado e metodicamente executado, de acordo com o progresso paralelo dos meios de transportes marítimo e terrestre e com as necessidades das regiões a que deve servir.

Essa falta de "planejamento" de uma política portuária nacional levou à superabundância de diversos portos na costa brasileira, construídos de forma aleatória e sem relação econômica com a sua hinterland. Cada estado, além de pleitear o melhoramento de seu porto principal, para atender a interesses locais, defendia a construção de novos portos para atender a demandas específicas. Muitas vezes, era ignorada a presença de um porto no estado vizinho, que facilmente poderia atender às demandas específicas, para contemporizar os compromissos políticos.

Neste caso, as fronteiras entre os Estados perdem o simples caráter de meras linhas de separação de sistemas administrativos diferentes e se erigem, perigosamente, em barreiras reais de interesses econômicos diversos e antagônicos, colidindo-se, paradoxalmente, dentro da própria Federação. Muitos Estados esforçam-se pela construção, não de um, mas de vários portos, ao longo do trecho de costa compreendido entre seus limites, sem que, todavia, a renda de todos, somada, baste para garantir, sequer, os juros correspondentes aos capitães empregados num só deles (Góes, 1930, p. 4-5). 
Góes defendia a realização de um programa geral de construção de portos, "inteligentemente estudado", que contemplasse uma visão geral do conjunto da nação. Os portos deveriam ser classificados numa hierarquia, destacando os principais portos organizados e sua grande área de abrangência. Os pequenos portos tributários deveriam ter um caráter "nitidamente temporário", e seu funcionamento dependeria da "marcha evolutiva das necessidades de cada um deles" (Góes, 1930, p. 7). Essa foi a visão que norteou a política portuária brasileira nas décadas seguintes.

\section{Centralização e planejamento: reaparelhamento e consolidação de um sistema portuário nacional 1934-1990}

Durante os anos 1934 a 1990, passamos por vários regimes políticos, mas, até 1980, seguiu ininterruptamente um longo período de industrialização, e o período restante, 1980-1990, foi de manutenção do parque industrial instalado. Nesse longo período de industrialização, o Estado brasileiro assumiu formas superiores de organização capitalista, orientando o processo de acumulação por meio do planejamento e do financiamento, além de políticas cambiais (orçamento cambial) e monetárias mais flexíveis voltadas para o crescimento. O Plano de Metas (1956-1961) e o II PND (1975-1978) são dois exemplos que cristalizaram os objetivos do Estado para a formação de um sistema nacional de economia.

A partir de 1934, temos que pensar a evolução dos portos dentro do "projeto nacional de industrialização" comandado pelo Estado. Do ponto de vista institucional, ocorreram quatro mudanças: a criação do Departamento Nacional de Portos e Navegação em 1934, alterado em 1943 para Departamento Nacional de Portos, Rios e Canais, transformado em autarquia em 1963 como Departamento Nacional de Portos e Vias Navegáveis e em Portobrás em 1975, uma empresa holding. Do ponto de vista jurídico, foram instituídos dois regimes portuários. $\mathrm{O}$ primeiro foi com o Decreto 24.599, em 1934, e o segundo, com o Decreto-Lei 749, em 1969. Dentro do ideal de planejamento, foram elaborados sete planos específicos para os portos nacionais.

\subsection{Centralizando as ações e racionalizando os recursos}

O Estado que surgiu após a Revolução de 1930, além de ampliar a sua base de atuação, passou a centralizar, burocratizar e racionalizar ainda mais as suas funções. Segundo Draibe "velhos órgãos ganharam nova envergadura, estruturaram-se gradativamente as carreiras, assim como os procedimentos sujeitaram-se crescentemente à lógica racional-legal" (1985, p. 62). Do ponto de vista econômico, os anos 1930 inauguram também um novo padrão de acumulação, o da industrialização restringida. Já podemos falar em industrialização, porém ela é limitada pela baixa capacidade de importar e pelas 
débeis bases técnicas e financeiras, cuja acumulação era horizontal, incapazes, portanto, de comandarem e financiarem os investimentos necessários para o país constituir "forças especificamente capitalistas de produção". Há, nesse período, um crescimento do departamento de bens de produção. No entanto, ainda é insuficiente para atender as necessidades da economia que estava em franca expansão (Cardoso de Mello, 1988).

É no bojo desse movimento de centralização que são fundidas as ações da Inspetoria de Portos, Rio e Canais com as da Inspetoria Federal de Navegação, criando o DNPN (Departamento Nacional de Portos e Navegação), regido pelo Regulamento aprovado em agosto de 1933, cujas atribuições eram as seguintes:

a) estudar, projetar, executar ou fiscalizar as obras de melhoramento dos portos e das vias navegáveis do país;

b) organizar, executar ou fiscalizar a conservação e a exploração comercial das vias navegáveis e dos portos melhorados;

c) estudar, organizar e fiscalizar a navegação mercante marítima, a interior e a interna dos portos;

d) organizar as estatísticas do tráfego dos portos, das vias navegáveis e da navegação mercante;

e) coordenar todos os elementos informativos sobre a construção naval, na parte relativa à navegação mercante, e sobre a exploração comercial dos portos, das vias navegáveis e da navegação marítima, interior e interna dos portos (Ministério da Viação e Obras Públicas, 1937a, p. 4).

Segundo o Diretor do DNPN, o engenheiro Frederico Cezar Burlamaqui, a criação desse novo órgão técnico tinha o "intuito de centralizar em uma só direção serviços que têm, entre si, grandes e íntimas ligações" (Ministério da Viação e Obras Públicas, 1937a, p. 4).

O novo órgão foi criado para solucionar os velhos problemas portuários, agora também os da navegação fluvial e marítima a vapor. Velhos problemas portuários que se arrastavam, como o das "parcas possibilidades financeiras" (Ministério da Viação e Obras Públicas, 1937b, p. 3). Com exceção dos Portos de Santos, Rio de Janeiro e Manaus, os demais portos organizados ainda careciam de novos investimentos e conservação, sem falar dos vários pequenos portos, ou trapiches, espalhados pela costa brasileira. Esses pequenos portos, tanto quanto os grandes, também pleiteavam melhoramentos, que em muitos casos eram atendidos, mas o ritmo das obras sempre foi muito lento. Segundo Burlamaqui, "muito já se tem conseguido levar a efeito, mas muito há ainda a se fazer no que diz respeito ao melhoramento e exploração comercial dos nossos portos" (Ministério da Viação e Obras Públicas, 1937b, p. 3). Nesse mesmo Relatório, 
Burlamaqui denunciava que ainda não haviam sido instalados os Distritos de Aparelhagem no Norte e no Sul, criados com o Regulamento dos Portos Organizados em 1922, ou seja, a espera já era de 15 anos (p. 8).

Na Mensagem Presidencial de 1933, Getúlio Vargas fez a seguinte observação sobre os portos:

O aparelhamento dos portos nacionais, não é supérfluo observar, tem sido encarado até agora com lamentável desatenção. Possuímos, certamente, grandes ancoradouros, dispondo de instalações completas e até suntuosas, como as dos grandes portos abertos ao intenso tráfego da navegação internacional. Não se pode chamar a isso, porém, obra completa de organização portuária, principalmente, num país de extensa costa e com toda a circulação da sua economia dependente das comunicações marítimas (Brasil, 1933, p. 90).

Os ancoradouros em alguns estados que estavam em situação muito precária, segundo a Mensagem, deveriam ser dotados de "recursos e instalações adequadas". Mas, ressalta a Mensagem, os melhoramentos deveriam ser feitos com "rigoroso critério de economia e fora de qualquer preocupação grandiosa" (Brasil, 1933, p. 90).

O Decreto 24.599, de 6 de julho de 1934 inaugurou um novo regime para os portos brasileiros, revogando as leis de concessão de 1869 e 1886 . Neste novo regime, o governo ficava autorizado a contratar para o melhoramento e exploração dos portos, por meio da concessão, os estados ou empresas privadas num prazo nunca superior a 70 anos.

Em abril de 1931 foi nomeada, pelo ministro da Viação e Obras Públicas, uma comissão de técnicos para elaborar um plano nacional de viação. $\mathrm{O}$ resultado final dessa comissão foi o primeiro Plano Geral da Viação Nacional, aprovado pelo Decreto-Lei 24.497, de 29 de junho de 1934, onde não aparece destaque algum para os portos. Com base no Plano, a partir dos anos 1940, a ênfase maior foi dada às rodovias; na verdade, o plano seguia o movimento geral da história dos transportes do Brasil, que priorizou inicialmente a navegação, em seguida as ferrovias e, por último, as rodovias. Em raros momentos, e circunscrita a algumas regiões brasileiras, houve uma integração das diversas modalidades de transportes. No passado, quando a economia brasileira estava "voltada para fora", as ferrovias convergiam para os portos. Agora, com a economia "voltada para dentro", as rodovias cumprem os objetivos de integração do mercado interno.

\subsection{Os planos específicos para os portos}

Nos anos 1940 e 1950 houve uma rápida transformação industrial e política em todo o território nacional. Durante o primeiro governo Vargas (19301945), foram elaborados pelos técnicos do Dasp (Departamento Administrativo do Serviço Público) dois planos de desenvolvimento: o Plano Especial de Obras 
Públicas e Aparelhamento da Defesa Nacional de 1939 e o Plano de Obras e Equipamentos (POE) de 1943. O Plano Especial foi aprovado para um período de cinco anos e foram destinados, ao todo, 20,17\% dos recursos ao Ministério da Viação e Obras Públicas. Em 1943, foi elaborado o Plano de Obras e Equipamentos e nos dois anos de execução, foram destinados ao Ministério da Viação e Obras Públicas 57,11\% dos recursos (Decretos-Leis 1.058/1939 e 6.145/1943). No governo Dutra (1946-1950), em 1948, o Dasp elaborou o Plano Salte - Saúde, Alimentação, Transporte e Energia, aprovado somente em 1950. Do total dos gastos previstos, $57 \%$ eram destinados aos setores de transportes, subdivididos da seguinte forma: estrada de ferro, 66,11\%; estrada de rodagem; $11,13 \%$; subsetor aeroviário, 8,25\%; portos 5,82\%; melhoria da frota, 5\%; melhoria da navegabilidade de rios, $2,43 \%$ e oleodutos, $1,24 \%$. O Plano foi sendo cumprido parcialmente e, em 1952, foi abandonado por completo (Draibe, 1985).

Juscelino (1956-1961) foi mais ousado e elaborou e executou o Plano de Metas. Segundo Lessa (1982), o Plano se constituiu num projeto ousado que visava a implantar as bases da industrialização brasileira, e configurou-se na "mais sólida decisão consciente em prol da industrialização na história econômica do país" (p. 27). Comparando com os projetos industriais dos anos anteriores, o Plano de Metas foi algo intencionalmente induzido, com objetivos claros: implantar a indústria de bens de produção. O Plano de Metas "conferia prioridade absoluta à construção dos estágios superiores da pirâmide industrial verticalmente integrada e do capital social básico de apoio a esta estrutura" (p. 27). A participação estatal se explica pelo crescente aumento das demandas sociais, pela inércia empresarial e pela incapacidade do setor privado de fazer certos investimentos que demandavam recursos vultosos exigindo, assim, a presença estatal. Draibe afirma que o Plano Especial, o POE e o Salte eram limitados e não foram executados na sua plenitude, pois não havia órgãos para responder e cumprir as prioridades. Já o Plano de Metas alterou profundamente a base da estrutura industrial brasileira criando oferta à frente da demanda.

Nesse ambiente ideológico e paralelo à elaboração e execução dos planos de desenvolvimento foram criadas diversas comissões executivas com a missão de elaborar planos setoriais voltados para a indústria de base. Com relação ao sistema portuário, no início de 1946 foi realizado, no Rio de Janeiro, o II Congresso Brasileiro de Engenharia e Industrial, no qual foram apresentadas várias recomendações para as vias navegáveis e para os portos. Para estes, foram feitas as seguintes recomendações:

a) elaborar um plano diretor portuário dividindo o litoral em zonas de influências com os portos principais e secundários, dando sempre prioridade aos portos principais;

b) criar novas facilidades para incrementar comercialmente os portos; 
c) elaborar o Caderno de Encargos. (Ministério da Viação e Obras Públicas, 1949, p. 11-12)

Com base nestas recomendações, foi elaborado pelo DNPRC (Departamento Nacional de Portos, Rios e Canais, sucessor do DNPN), em 1947, o Plano de Reaparelhamento e Ampliação dos Portos Organizados, o primeiro plano nacional para os portos brasileiros. A previsão total de investimentos era de 1,3 bilhão de cruzeiros e a principal fonte de recursos viria da Taxa de Emergência criada em 1945 (Decreto-Lei 7.995/1945).

Elaborado durante o governo Dutra, o Plano de Reaparelhamento tinha verbas dentro do Plano Salte. Porém, mais uma vez, as obras realizadas nesse período foram executadas dentro das necessidades urgentes de cada porto, sem um plano global de investimento e conservação. Na última Mensagem enviada ao Congresso Nacional, o presidente Dutra fez a seguinte observação sobre obras portuárias em relação ao Plano e às dotações previstas:

Visava-se e visa-se, neste particular, ao gradativo reequipamento de nossos portos, que não será tão completo quanto desejáramos, mas pelo menos, em conformidade com os recursos financeiros disponíveis (Brasil, 1950, p. 279).

O Plano de Reaparelhamento foi aprovado somente no segundo governo Vargas (1951-1954), para ser executado em 4 anos, ou seja, de 1952 a 1955. No preâmbulo do Decreto 30.334/1951, que aprovou o Plano, há as seguintes considerações que retratam com muita propriedade a situação portuária nacional na época:

- Considerando que há necessidade urgente de se proceder ao melhoramento dos portos nacionais, mediante a drenagem, reaparelhamento e ampliação dos portos já existentes, conclusão das instalações portuárias em andamento e construção de outras;

- Considerando que o congestionamento de alguns portos vem causando sérios sacrifícios à economia da Nação, em virtude das sobretaxas criadas pelas conferências internacionais sobre os fretes das mercadorias de importação;

- Considerando que o intercâmbio por via marítima através dos portos tem revelado rápido ritmo de aumento nesses últimos anos, paralelamente ao desenvolvimento que se vem verificando na indústria nacional;

- Considerando que se trata de um problema de larga envergadura, a ser enfrentado com o máximo de energia e rapidez, embora dentro das possíveis disponibilidades de recursos em materiais e mão-de-obra especializada;

- Considerando que há necessidade de ampliar a frota de navegação, e, finalmente; 
- Considerando que o problema portuário e de navegação devem ser tratados num âmbito nacional.

Os valores e os prazos foram revistos, o plano geral estava orçado em 3,525 bilhões de cruzeiros, sendo que para os programas mais urgentes foram orçados 1,925 bilhão de cruzeiros em moedas nacionais e 800 milhões destinados a importações de equipamentos. Numa segunda etapa, estavam previstos investimentos na ordem de 1,140 bilhão de cruzeiros e para os aparelhamentos 460 milhões (Brasil, 1952, p. 202). A Comissão Mista Brasil-Estados Unidos se encarregou de elaborar projetos para reaparelhamentos em 14 portos brasileiros, cujos recursos seriam captados em bancos estrangeiros.

Tabela 1

Previsão de gastos do Plano de Reaparelhamento Nacional de Portos e Navegação 1952-1955 (em mil cruzeiros)

\begin{tabular}{l|c}
\hline Ano & Recursos orçados \\
\hline 1952 & 450.000 \\
\hline 1953 & 600.000 \\
\hline 1954 & 600.000 \\
\hline 1955 & 275.000 \\
\hline
\end{tabular}

Fonte: Decreto n. 30.334 de 21 de dezembro de 1951. Disponível em: $<$ http://www.senado.gov.br/servlets $>$. Acesso em: 18 ago. 2004.

Juscelino começou seu governo pedindo uma revisão no Plano de Reaparelhamento cuja execução estava retardada e os recursos reduzidos "à míngua", além disso, o presidente exigia que fossem revistos os projetos da Comissão Mista (Brasil, 1956, p. 435). Para Juscelino, os portos brasileiros não estavam "organizados e administrados como atividades econômicas" (Brasil, 1956, p. 436). Faltava um órgão central que coordenasse e orientasse as atividades de acordo com critérios econômicos e técnicos.

O atual Departamento Nacional de Portos, Rios e Canais, órgão de excelente tradição técnica, não é senão uma repartição de engenharia portuária, cujas funções específicas - obras civis e hidráulicas e serviços de drenagem - nada têm nem devem ter com a operação portuária, que é uma técnica própria, completamente diferenciada como gerência econômica do porto (Brasil, 1956, p. 437).

Para assumir novas e necessárias funções, o DNPRC deveria "reestruturarse e equipar-se convenientemente" centralizando e coordenando as "práticas e métodos econômicos" (Brasil, 1956, p. 437). Para tanto, foi encaminhado ao Congresso um projeto de lei que tinha como objetivo transformar o DNPRC numa autarquia, desvinculando diretamente do Ministério da Viação e Obras Públicas. Portanto, dez anos após a elaboração do Plano, pouca coisa havia sido feita. E, para resolver o problema da falta de recursos, foi encaminhado para o Congresso, no final de 1956, um projeto de lei para instituir o Fundo Portuário Nacional. 
Enquanto isso, as obras de ampliação e conservação seguiam em vários portos de acordo com as necessidades mais urgentes. Ao contrário dos setores siderúrgico, rodoviário e energético nos quais a oferta dava saltos à frente da demanda, no setor portuário, a oferta andava a reboque da demanda: "Dentro das limitações de recursos financeiros disponíveis, realizaram-se, em 1957, as obras de drenagem mais urgentemente reclamadas pela navegação" (Brasil, 1958, p. 168). Como a economia crescia de forma acelerada, o problema era constantemente reposto também de forma acelerada num nível de complexidade ainda maior.

A exemplo da taxa de $2 \%$ sobre importações e $1 \%$ sobre exportações de 1886, Caixa Especial Portuária de 1903 e da Taxa de Emergência de 1945, todas destinadas às obras de ampliação e conservação dos portos, a Lei 3.421 de 10 de julho de 1958 transformou a Taxa de Emergência em Taxa de Melhoramento dos Portos - TMP (1\% sobre as importações, $0,2 \%$ sobre as exportações e $0,2 \%$ sobre o comércio de cabotagem) que seria destinada ao Fundo Portuário Nacional - FPN (gerenciado pelo DNPRC), substituindo a Taxa de Emergência. Após a aprovação da TMP e do FPN foi criada a Comissão do Plano Portuário, vinculada ao DNPRC cuja função era basicamente elaborar um plano portuário nacional (Decreto 44.203/1958). A criação dessa comissão somente em 1958 revela a pouca prioridade dada ao sistema portuário nacional. Basta lembrar que nos anos de 1940 foram criadas comissões do plano siderúrgico, rodoviário e comércio exterior, e na primeira metade dos anos 1950 as comissões do plano do carvão e material elétrico.

Os recursos garantidos provenientes do FPN e de financiamentos externos na ordem de 22,5 milhões de dólares (15 milhões do Export-Import Bank e 7,5 milhões do IHC Holland) deram uma garantia e uma ampla margem de manobra para a Comissão elaborar o plano portuário.

Com a criação do Fundo Portuário Nacional, modificou-se, sensivelmente, o programa de trabalho do governo no setor portuário, tornando possível não somente a elaboração de um Plano Geral de melhoramento das respectivas instalações, mas, também a adoção de uma política de investimentos, com o objetivo de tirar o máximo proveito das instalações existentes e, bem assim, a transformação dos portos em organismos econômicos, capazes, portanto, de atender as exigências sempre crescentes da navegação (Brasil, 1959, p. 81).

Além do plano portuário, ficou determinado que cada porto deveria elaborar seu plano de reaparelhamento e execução. Em 1959, o Plano Portuário Nacional foi entregue ao presidente Juscelino e aprovado em julho de 1960 (Decreto 48.524/1960). O Plano previa investimentos na ordem de 23,4 bilhões de cruzeiros para o período de 1960 a 1962, distribuídos em expansão, melhoramentos, construção, estudos e aquisições. 
Quadro 2

Previsões de gastos do Plano Portuário Nacional 1960-1962 (em mil cruzeiros)

\begin{tabular}{|l|c|l|}
\hline Obras e serviços & Recursos previstos & \multicolumn{1}{|c|}{ Portos beneficiados } \\
\hline Expansão e melhoramento & 18.000 .000 & $\begin{array}{l}\text { Manaus, Belém, Mucuripe, Natal, Cabedelo, } \\
\text { Recife, Maceió, Aracaju, Salvador, Ilhéus, } \\
\text { Vitória, Rio de Janeiro, Niterói, Florianópolis, } \\
\text { Imbituba, Laguna, Rio Grande, Pelotas, Porto } \\
\text { Alegre e Corumbá }\end{array}$ \\
\hline $\begin{array}{l}\text { Construção de novos portos } \\
\text { Melhoramento de hidrovias }\end{array}$ & 1.400 .000 & $\begin{array}{l}\text { Macapá, Itaqui, Luiz Corrêa, Areia Branca, } \\
\text { Campinho, Malhado e Forno }\end{array}$ \\
\hline $\begin{array}{c}\text { Aquisição de equipamentos de } \\
\text { drenagem }\end{array}$ & 2.600 .000 & \\
\hline $\begin{array}{c}\text { Encargos diversos para } \\
\text { implantação do Plano } \\
\text { Portuário Nacional }\end{array}$ & 900.000 & \\
\hline $\begin{array}{c}\text { Estudos em laboratórios de } \\
\text { hidráulica experimental }\end{array}$ & 550.000 & \\
\hline Total & 23.400 .000 & \\
\hline
\end{tabular}

Fonte: Decreto n. 48.524 de 14 de julho de 1960. Disponível em: <http://www.senado.gov.br/servlets> Acesso em: 18 ago. 2004.

Dentro do Plano de Metas o setor de transportes requereu 29,6\% do total dos investimentos. Das operações em moeda estrangeira, o subitem "navegação, portos e dragagem" captou 5\% e das operações em moeda nacional captou apenas 0,9\%. Contudo, no final do governo JK, segundo Lessa (1982, p. 41), em termos do movimento nos portos, o resultado foi "bastante insatisfatório". Deveriam ser realizadas grandes obras nos Portos de Santos, Rio de Janeiro e do Rio Grande, além de obras menores em outros 10 portos. Os projetos foram reelaborados e reduzidos às necessidades mais urgentes com financiamento do BNDES (BNDES, 1996).

Com a renúncia do presidente Jânio Quadros em 1962, o vice-presidente João Goulart assume o governo sob o regime parlamentarista. Na Mensagem enviada ao Congresso Nacional em 1963, Goulart denuncia que no período 19561961 houve um "crescimento relativamente mais intenso das rodovias, em detrimento de outros setores, como, por exemplo, o de portos" (Brasil, 1963, p. 77). Durante o curto governo Goulart, foi finalizado o segundo Plano Nacional de Viação (aprovado pela Lei 4.592/1964) e iniciada a execução do Plano Trienal de Desenvolvimento Econômico e Social 1963-1965, que previa crescimento anual do PIB de 7\%. Para os portos, estava previsto no Plano Trienal: a) reestruturar os serviços do DNPVN (Departamento Nacional de Portos e Vias Navegáveis), agora como autarquia; b) ministrar cursos para administradores portuários; c) dar atenção ao problema do congestionamento; e, e) investir em instalações para granéis (Brasil, 1963). 
Em outubro de 1963, finalmente, após sete anos de tramitação do projeto no Congresso, o DNPRC foi transformado em DNPVN (Departamento Nacional de Portos e Vias Navegáveis), uma autarquia com autonomia administrativa, técnica e financeira em relação ao Ministério da Viação e Obras Públicas. Com relação ao Plano Portuário Nacional, em abril de 1963, houve atualização prevendo investimentos até 1966 na ordem de 71,8 bilhões de cruzeiros. Contudo, a execução do Plano Trienal foi abortada pelo golpe militar.

Quadro 3

Previsões de gastos do Plano Portuário Nacional 1963-1966 (em mil cruzeiros)

\begin{tabular}{|c|c|c|}
\hline Obras e serviços & Recursos previstos & Portos beneficiados \\
\hline Expansão e melhoramento & 47.890 .000 & $\begin{array}{l}\text { Manaus, Belém, Mucuripe, Natal, Cabedelo, } \\
\text { Recife, Maceió, Aracaju, Salvador, Ilhéus, Vitória, } \\
\text { Rio de Janeiro, Niterói, Angra dos Reis, São } \\
\text { Sebastião, Santos, Paranaguá, Itajaí, Imbituba, } \\
\text { Laguna, Rio Grande, Pelotas e Porto Alegre }\end{array}$ \\
\hline Construção de novos portos & 7.080 .000 & $\begin{array}{l}\text { Macapá, Itaqui, Areia Branca, Macau, Campinho, } \\
\text { Malhado e Forno }\end{array}$ \\
\hline $\begin{array}{l}\text { Encargos diversos com a } \\
\text { aquisição de equipamentos } \\
\text { e dragagem }\end{array}$ & 7.440 .000 & \\
\hline $\begin{array}{l}\text { Melhoramento de hidrovias } \\
\text { interiores }\end{array}$ & 4.660 .000 & \\
\hline $\begin{array}{l}\text { Encargos diversos com a } \\
\text { implantação do PPN }\end{array}$ & 2.100 .000 & \\
\hline $\begin{array}{l}\text { Encargos diversos com } \\
\text { expansão, melhoramento e } \\
\text { construção de porto e } \\
\text { hidrovias }\end{array}$ & 1.490 .000 & \\
\hline $\begin{array}{l}\text { Aquisição de equipamentos de } \\
\text { drenagem }\end{array}$ & 900.000 & \\
\hline $\begin{array}{l}\text { Estudos e implantação do } \\
\text { Laboratório de Hidráulica } \\
\text { Experimental }\end{array}$ & 240.000 & \\
\hline Total & 71.800 .000 & \\
\hline
\end{tabular}

Fonte: Decreto n. 51.899 de 10 de abril de 1963. Disponível em: <http://www.senado.gov.br/servlets> Acesso em: 18 ago. 2004.

No início da ditadura militar, em 1965, foi criado o Geipot (Grupo Executivo para a Integração das Políticas de Transportes) pelo Decreto 57.003/1965, que intensificou a elaboração de planos específicos para as diversas modalidades de transportes. O primeiro grande plano portuário organizado pelo DNPVN em convênio com o Geipot foi o Plano Diretor Portuário do Brasil 19751984. Esse plano estava dividido em três níveis de prioridade: obras prioritárias, obras recomendadas e obras a serem confirmadas. As obras prioritárias representavam aquelas em que a definição e a cronologia eram certas, e a 
realização seria imediata devido à forte pressão da demanda. As obras recomendadas se pautavam nas "perspectivas realistas do fluxo de carga". E as obras a serem confirmadas estariam sujeitas à confirmação da previsão de cargas e de estudos de viabilidade (Ministério dos Transportes, 1974). Ao todo, estava previsto um investimento de 9,77 bilhões de reais, distribuído em 25 portos.

Tabela 2

Previsão de gastos no Plano Diretor Portuário do Brasil 1975-1984 (em mil cruzeiros)

\begin{tabular}{|c|c|c|}
\hline Porto & Valor & $\mathrm{Em} \%$ \\
\hline Santos & 3.064 .035 & 31,36 \\
\hline Itaqui & 1.579 .379 & 16,16 \\
\hline Rio de Janeiro & 1.478 .209 & 15,13 \\
\hline Vitória & 1.265 .552 & 12,95 \\
\hline Rio Grande & 605.897 & 6,20 \\
\hline Paranaguá & 330.267 & 3,38 \\
\hline Manaus & 320.461 & 3,28 \\
\hline Recife & 245.426 & 2,51 \\
\hline São Sebastião & 138.621 & 1,42 \\
\hline Salvador & 122.232 & 1,25 \\
\hline Imbituba & 119.430 & 1,22 \\
\hline S. F. do Sul & 113.425 & 1,16 \\
\hline Fortaleza & 98.033 & 1,00 \\
\hline Aracajú & 66.170 & 0,68 \\
\hline Belém & 49.880 & 0,51 \\
\hline Maceió & 48.870 & 0,50 \\
\hline Estudos Gerais & 30.000 & 0,31 \\
\hline Angra dos Reis & 28.874 & 0,30 \\
\hline Itajaí & 9.006 & 0,09 \\
\hline Santarém & 8.662 & 0,09 \\
\hline Natal & 7.976 & 0,08 \\
\hline Cabedelo & 5.915 & 0,06 \\
\hline Ilhéus & 3.903 & 0,04 \\
\hline Forno & 525 & 0,01 \\
\hline Pelotas & 330 & 0,003 \\
\hline Total & 9.770 .505 & 100,00 \\
\hline
\end{tabular}

Para continuar com o mesmo ritmo de crescimento herdado do "milagre econômico", manter expectativas, superar a crise e completar o parque industrial brasileiro, em meados de 1974, é apresentado à Nação o II PND (Plano Nacional de Desenvolvimento). Com o II PND (1975-1978), tardiamente, a economia brasileira deu um salto, internalizando os adventos da segunda revolução industrial, permitindo um crescimento médio no período de $7 \%$ ao ano. Dentro do II PND, para o setor de transportes havia uma previsão de crescimento para as 
rodovias de $45,6 \%$, para as ferrovias de $124 \%$ e para a navegação $124 \%$. Além disso, estava previsto reorganizar o DNPVN transformando-o numa empresa de capital aberto (Brasil, 1975). Em paralelo à execução do II PND, estavam sendo cumpridas algumas das metas estabelecidas no Plano Diretor Portuário.

Os investimentos do DNER saltaram de 234,7 milhões de dólares em 1970 para 476,2 milhões em 1979; da RFFSA, de 82,7 milhões para 404,1 milhões; e da Portobrás, de 29,4 milhões para 135,8 milhões de dólares. No total, os investimentos no sistema de transportes, incluindo outros setores e modalidades, saltaram de 520,5 milhões de dólares em 1970 para 1.691,3 milhões em 1979, ou seja, um aumento de 225\% (Barat, 1996, p. 268-269).

Em 1979, houve uma revisão do Plano Diretor Portuário do Brasil de 1975, e foram feitas algumas alterações ampliando a previsão da realização das obras para 1988. E, em 1986, novamente houve outra reformulação e ampliação do Plano de 1979, quando foi elaborado o Plano de Desenvolvimento Portuário 1987-1996, que tinha como objetivo implementar melhorias e construir novas instalações, com intenção de reduzir o custo global dos transportes (Ministério dos Transportes, 1986). Ao longo dos anos 1980, os planos portuários de 1975-1984 e de 1987-1996 ficaram condicionados à disponibilidade de recursos e sofreram constantes contingenciamentos orçamentários. Era uma época em que a prioridade era conter os gastos públicos. Com isso, os problemas portuários não solucionados nos anos de rápido crescimento da economia, anos 1950-1980, foram se avolumando ainda mais nos anos 1980.

Com a redemocratização após 1985, o governo da Nova República elaborou um novo plano de desenvolvimento, o I PND-NR 1986-1989 (I Plano Nacional de Desenvolvimento da Nova República), que fazia um amplo e crítico diagnóstico da economia brasileira dos últimos 20 anos. O I PND-NR previa um crescimento contínuo de $6 \%$ ao ano distribuindo renda e combatendo a pobreza. $\mathrm{O}$ diagnóstico do setor de transportes revelava que nos últimos vinte anos houve uma concentração dos investimentos na pavimentação de rodovias, no transporte ferroviário urbano e nos corredores de exportações, em detrimento de outras modalidades. Dado o endividamento externo, a crise fiscal e financeira e a quebra do padrão de financiamento engessaram o Estado; na prática, poucas metas do I PND-NR foram cumpridas. O país estava mergulhado na "década perdida" e entrando na era neoliberal.

Dentro do ideário da Nova República, paralelo ao I PND-NR, para os portos foi elaborado o Plano de Desenvolvimento Portuário 1987-1996, o último plano global elaborado para os portos brasileiros. Junto com esses dois planos também foi elaborado um plano mais global para o setor de transporte, o Prodest (Programa de Desenvolvimento do Setor de Transportes), que seguia as metas do 
I PND-NR e previa uma série de investimentos a serem executados pelas estatais ligadas ao setor de transportes. Especificamente, o diagnóstico feito pelo PRODEST para os portos brasileiros era o seguinte (Brasil, 1986a, p. 9-11):

- Inexistência de uma política portuária nacional.

- Inadequação do atual sistema do aporte de recursos financeiros para investimento e custeio.

- Inadequação do atual sistema tarifário.

- Desvinculação da receita do TMP (Decreto 1.859, 17/2/81).

- Carência de auto-sustentação financeira do sistema Portobrás.

- Ausência de participação de capital privado no sistema.

O Prodest atuaria em três frentes no sistema portuário: racionalização das operações portuárias, novos investimentos e capacitação dos recursos humanos. De certa forma, o Prodest incorporou as metas do Plano de Desenvolvimento Portuário de 1987. A distribuição dos gastos pode ser acompanhada na tabela abaixo.

Tabela 3

Previsão de gastos para os portos dentro do Prodest 1986-1989 (em Cz\$ 10/6)

\begin{tabular}{l|c|c|c}
\hline Ano & $\begin{array}{c}\text { Racionalização das } \\
\text { operações portuárias }\end{array}$ & Investimentos & Recursos humanos \\
\hline 1986 & & $1.325,31$ & \\
\hline 1987 & 20,06 & $2.945,42$ & 4,18 \\
\hline 1988 & 14,93 & $5.622,12$ & 10,82 \\
\hline 1989 & 4,00 & $4.677,15$ & 10,00 \\
\hline
\end{tabular}

Fonte: Brasil. Prodest - Programa de Desenvolvimento do Setor de Transportes 1986-1989.

Brasília: Ministério dos Transportes, 1986.

O Prodest sofreu uma nova alteração em 1988, e o período de atuação foi ampliado para 1991. Com a entrada de Fernando Collor na Presidência em março de 1990, o Prodest foi abandonado.

Dentro dos dois últimos planos (1975 e 1987) e da revisão do Plano de 1974 feita em 1979, foi elaborado para cada porto um estudo específico com previsão de movimento de cargas e de ampliação. Dentro dos recursos liberados pelo Ministério dos Transportes, as obras eram executadas. Porém, em 1981, com a desvinculação da TMP da Portobrás, a empresa entrou num rápido processo de descapitalização prejudicando a execução das obras. 
Melhoramentos, reaparelhamentos e modernização dos portos brasileiros: a longa e constante espera

Quadro 4

Aspectos gerais dos planos portuários nacionais

\begin{tabular}{|c|c|c|c|}
\hline Plano portuário & Período & Governo & Plano nacional \\
\hline $\begin{array}{l}\text { Plano de Reaparelhamento e Ampliação } \\
\text { dos Portos Organizados }\end{array}$ & Elaborado em 1947 & Eurico Gaspar Dutra & Plano SALTE \\
\hline $\begin{array}{l}\text { Plano de Reaparelhamento Nacional de } \\
\text { Portos e Navegação }\end{array}$ & $1952-1955$ & Getúlio Vargas & \\
\hline Plano Portuário Nacional & $1960-1962$ & Juscelino Kubitschek & Plano de Metas \\
\hline Plano Portuário Nacional & $1963-1966$ & João Goulart & Plano Trienal \\
\hline Plano Diretor Portuário do Brasil & $1975-1984$ & Ernesto Geisel & II PND \\
\hline $\begin{array}{l}\text { Revisão do Plano Diretor Portuário do } \\
\text { Brasil }\end{array}$ & $1979-1988$ & João Figueiredo & III PND \\
\hline Plano de Desenvolvimento Portuário & $1987-1996$ & José Sarney & I PND-NR \\
\hline
\end{tabular}

Fonte: Planos específicos para os portos e os planos nacionais.

\subsection{Integração das políticas de transportes e a criação da Portobrás}

A criação do Geipot em 1965 foi fruto do amadurecimento das políticas de transportes e das críticas feitas pelos técnicos do Ministério em relação aos desencontros de políticas para as diversas modalidades. Os planos ferroviário, rodoviário e portuário necessariamente deveriam estar integrados com a política nacional de desenvolvimento. O Geipot veio para dar essa contribuição, integrando a política de transportes por meio de estudos e planos articulados com os objetivos de crescimento da economia nacional. Mesmo com a intenção de integrar as várias modalidades, a prioridade ainda não havia mudado, e as rodovias continuaram predominando na agenda do Ministério da Viação e Obras Públicas, transformado em Ministério dos Transportes em 1967.

No final dos anos 1960, o Geipot começou a apresentar vários estudos que apontavam a necessidade de se pensar a política de transportes de forma integrada entre as várias modalidades. Os conceitos de transporte modal, hinterland portuária e corredores de exportações passaram a ter mais consistência. Os primeiros estudos do Geipot foram planos diretores decenais para os setores ferroviário, rodoviário, portuário e marítimo, concluídos em 1967. Esses planos inicialmente contaram com apoio financeiro do BIRD (Banco Interamericano de Reconstrução e Desenvolvimento) e apoio técnico da ONU (Organização das Nações Unidas) (Grupo Executivo de Integração da Política de Transportes, 1967). Também como resultado dos estudos do Geipot, em 1973, foi aprovado o terceiro, e o último, Plano Nacional de Viação (Lei 5.917/1973).

Um dos importantes estudos do Geipot foi o Programa dos Corredores de Exportação, criado com objetivo de facilitar, assegurar e aumentar o fluxo de mercadorias mais exportáveis na agricultura, mineração e siderurgia. Alguns portos, ferrovias e rodovias foram selecionados para receber novos investimentos. Os principais portos selecionados foram Rio Grande, Paranaguá - construções de 
terminais para cereais; Santos - construção de terminal para contêineres; e Vitória - construção de terminais para minério de ferro. Neles deveriam ser construídos terminais de alta capacidade para movimentação de carga específica. Também faziam parte do Programa os terminais açucareiros de Recife e Maceió, o terminal salineiro de Areia Branca, o terminal cacaueiro de Porto Malhado em Ilhéus e os terminais para minérios em Sepetiba e Tubarão. Os corredores eram a concretização de uma visão integrada da infra-estrutura de transportes voltados para exportações (Peixoto, 1977).

A partir do golpe militar de 1964, os transportes também passaram a ser vistos pela égide da Lei de Segurança Nacional. Na Mensagem Presidencial de 1968, de Arthur da Costa e Silva, há a seguinte passagem sobre a nova política de transportes (Brasil, 1968, p. 56):

Ao estabelecer a atual política de transportes, o Governo teve em mente dotar o país de uma infra-estrutura adequada às necessidades imediatas e futuras, bem como promover a integração das várias modalidades de transportes, objetivando reduzir os custos operacionais dos serviços e aumentar a produtividade de todo o sistema.

O regime portuário da ditadura foi condensado no Decreto 749/1969, que autorizou a União a constituir sociedades de economia mista ou empresas públicas destinadas a explorar os portos, terminais e as vias navegáveis.

Analisando os Relatórios e os Informativos do DNPVN de 1965 a 1969, é perceptível a mudança nos discursos, agora exaltando a grandeza nacional e o bom desempenho dos portos, desaparecendo as reclamações e críticas ao sistema portuário. O Relatório de 1965 traz uma solicitação de reestruturação do DNPVN mediante a criação de órgãos regionais autônomos.

Para que o DNPVN ficasse em condições de supervisionar com eficiência a realização da política portuária do Governo, foi estudada a sua reestruturação administrativa, tendo em vista a necessidade, manifesta, da descentralização de seus serviços, através da criação de órgãos regionais adequados, e da distribuição de suas duas atividades essenciais, relativas aos portos e às vias navegáveis, em órgãos centrais distintos dotados da necessária autonomia de ação (Ministério da Viação E Obras Públicas, 1965, p. 5).

Em 1969, o diretor do DNPVN, Luiz Henrique Palumbo Targat, fez as seguintes considerações sobre as "supostas deficiências dos portos":

Hoje entendemos que as supostas deficiências dos portos estão diretamente ligadas a inúmeros outros fatores que lhes são estranhos: a falta de planejamento por parte dos usuários (importadores e exportadores), a falta de transporte terrestre em condição de acompanhar o fluxo de navios em época de maior procura das instalações portuárias e o acondicionamento de determinadas cargas, como os granéis sólidos, em navios de carga geral, dificultando a operação portuária (Departamento Nacional de Portos e Vias Navegáveis, 1969, p. 5). 
Ou seja, o problema não era dos portos, do Estado, e sim dos agentes privados.

Com a aprovação do Fundo Portuário Nacional (FPN) e da Taxa de Melhoramento dos Portos (TMP) e a retomada do crescimento da economia brasileira após 1967, houve uma ampliação dos investimentos em reaparelhamento e conservação dos portos. Dentro dos estudos elaborados pelo Ministério dos Transportes entre 1973 e 1974, começou a ser apresentada uma proposta de criação de uma empresa holding para a administração do sistema portuário (Mello, 1974). Durante a excussão do II PND, em julho de 1975, foi extinto o DNPVN, que se transformou em Portobrás (Empresa de Portos do Brasil S.A.), cuja finalidade, entre outras, segundo o seu estatuto, era administrar e explorar os portos brasileiros (Lei 6.222/1975 e Decreto 76.925/1975). A organização da empresa holding Portobrás era vista como um importante passo para a integração do sistema portuário nacional criando mais flexibilidade organizacional, administrativa, financeira, técnica e operacional. Como das outras vezes, desde a criação das Capitanias dos Portos em 1845, as esperanças foram renovadas.

Com a criação da Portobrás, inicialmente, os portos mais beneficiados foram aqueles que estavam dentro dos corredores de exportação, uma vez que era necessário melhorar a situação do Balanço de Pagamento. Os portos ligados ao complexo siderúrgico também foram aparelhados, já que os minérios também faziam parte da pauta de exportação, destacando o Complexo Carajá. Também foram reaparelhados os portos que contribuíam na racionalização de energia e derivados de petróleo, como o porto carvoeiro de Imbituba, em Santa Catarina.

A rápida introdução do contêiner como meio para transportar as cargas exigia renovação constante dos equipamentos portuários. O diagnóstico feito pelo I PND-NR (I Plano Nacional de Desenvolvimento da Nova República) em 1986 já apontava esse problema, afirmando que, mesmo com algum êxito obtido pela política de transportes, o setor sofreu com a contenção dos gastos e a postergação das soluções, prejudicando até a manutenção e conservação das estruturas existentes. O resultado dessa postergação, segundo o Plano, foi "a deterioração crescente do capital fixo de todas as modalidades (rodovias, ferrovias, hidrovias, aeroportos, portos, terminais etc.)" (Brasil, 1986b, p. 110). Como as metas do I PND-NR e do Prodest não foram sendo cumpridas, o governo começou a elaborar uma nova Política Nacional de Transportes que apontava para a "descentralização e para a privatização" no setor (Brasil, 1989, p. 57). Na última Mensagem enviada ao Congresso Nacional, o presidente José Sarney reconhecia que os problemas portuários eram consideráveis e que a causa era a "reduzida capacidade de investimento", dada a descapitalização da Portobrás, que se constituía "no principal obstáculo à reabilitação do setor"' (Brasil, 1990, p. 100). 
O Brasil chegou ao final da década de 1980 com a infra-estrutura social básica estrangulada. A criação da Portobrás foi mais uma tentativa ilusória de que, com apenas uma nova organização institucional, os problemas portuários seriam solucionados. Ledo engano, a espera continuava. A vitória de Fernando Collor para a Presidência animou os liberais, que sonhavam com a privatização dos portos como a única saída para a modernização portuária.

\section{Modernização e privatização dos portos: novamente a espera do privado pós- 1990}

No dia 15 de março de 1990, ou seja, no mesmo dia da posse do presidente Fernando Collor de Mello, foi baixada a Medida Provisória n. 151, que extinguiu e dissolveu cinco autarquias, oito fundações, três empresas públicas e oito sociedades de economia mista. Entre as empresas, estava a Portobrás. Após 70 anos de ampliação das funções institucionais dos diversos órgãos que foram criados para gerenciar os portos brasileiros, desde a IFPRC, numa simples medida provisória foi desmontada toda a estrutura da Portobrás. Para os portos brasileiros, a extinção da Portobrás marcou o início de uma confusão administrativa e uma rápida deterioração das estruturas. Do ponto de vista da hierarquia administrativa, as companhias docas e os demais departamentos simplesmente ficaram "soltos". O Brasil estava entrando na era neoliberal.

Mais do que o sistema portuário, o governo Collor pôs fim às políticas de transportes, inclusive com a extinção do Ministério do Transportes, que foi reduzido a uma Secretaria dentro do Ministério da Infra-Estrutura, juntamente com as Comunicações e Minas e Energia. Se a estrutura portuária vinha se deteriorando nos anos 1980, com o fim da Portobrás a situação se complicou mais ainda. As obras foram paralisadas, as licitações foram suspensas e os projetos foram encerrados. No quadro funcional da já extinta Portobrás, a situação foi de espanto e de expectativa com o que viria pela frente após a absurda façanha. A solução imediata foi criar o Departamento de Portos dentro da Secretaria de Transportes, ou seja, a estrutura de uma grande empresa holding transformou-se num departamento. Parte das funções da Portobrás foram assumidas pelas companhias docas estaduais, como o INPH (Instituto Nacional de Pesquisas Hidroviárias), que passou para a Companhia Docas do Rio de Janeiro.

Com o desmembramento do Ministério da Infra-Estrutura e a volta do Ministério dos Transportes em 1993, os portos passaram a ser coordenados pelo Departamento Nacional de Transportes Aquaviários. Atualmente, o órgão responsável pelos portos é a Antaq (Agência Nacional de Transportes Aquaviários), criada pela Lei 10.233, de 5 de julho de 2001, cujas áreas de atuação são a navegação fluvial e lacustre, os portos organizados, os terminais portuários privativos e o transporte aquaviário de cargas especiais e perigosas. A Antaq 
implementa as políticas formuladas pelo Ministério dos Transportes e pelo Conit (Conselho Nacional de Integração de Política de Transportes). No início do século $\mathrm{XX}$ criavam-se as inspetorias, no início da era do planejamento, as autarquias, e depois, os militares centralizaram em grandes empresas holding. Na era neoliberal, tudo é desmontado, ficando sob responsabilidade das agências reguladoras, que não têm nenhuma capacidade de investimento.

A Lei de Modernização dos Portos, 8.630 de 25 de fevereiro de 1993, trouxe algumas novidades, mas, como na Lei de 1869, aposta na iniciativa privada como a única solução para reverter o grave problema portuário. Os pilares básicos da Lei de Modernização são: a) a ampliação do direito à iniciativa privada de fazer as operações portuárias, que na prática significou a privatização dos portos, criando a figura do operador portuário; b) a criação do Ogmo (Órgão Gestor da Mão-de-Obra), entidade responsável em administrar o fornecimento da mão-deobra do trabalhador portuário avulso, quebrando o monopólio dos sindicatos; c) a criação da Administração Portuária, sob responsabilidade das companhias docas estatais; e d) a instituição do Conselho de Autoridade Portuária cuja função é deliberar sobre as regras de funcionamento de cada porto, formado por três blocos: poder público, operadores portuários e trabalhadores portuários.

A abertura comercial dos anos 1990 foi feita sem que os portos estivessem preparados para tanto fluxo de mercadorias importadas. Na primeira metade dos anos 1990, o fluxo aumentou consideravelmente. Por outro lado, os incentivos destinados para as exportações não foram seguidos de melhorias na estrutura portuária. Depois da desvalorização de 1999 e do superaquecimento da economia chinesa, as exportações brasileiras seguiram num ritmo acelerado de crescimento.

Nos últimos 20 anos não foi elaborado mais nenhum plano global de investimentos com objetivos nacionais. Os parcos investimentos feitos pelo Estado na infra-estrutura social básica foram executados para atender as necessidades mais urgentes, não ampliando a estrutura da oferta na frente da demanda. Com isso, rapidamente o sistema de transportes fica estrangulado e exige novos investimentos para reparar danos e ampliar a capacidade de oferta. Malha rodoviária estrangulada, falta de investimentos nos aeroportos, deficiência na estrutura portuária, ferrovias obsoletas e baixos investimentos nas hidrovias, este é o cenário do "apagão logístico" brasileiro no final da década de 1990. Num país com graves problemas na infra-estrutura social básica, insistir em superávit primário e altas taxas de juros, e com crescimento médio anual do PIB de 2,5\% nos últimos 25 anos, o "apagão logístico" é reforçado constantemente. O problema do sistema portuário é secular. Não é a falta de uma lei, de uma nova autarquia ou de uma agência; como em toda infra-estrutura social básica brasileira, o que falta são investimentos vultosos, pois os portos são estruturas gigantes. Os investimentos são feitos, porém bem aquém das necessidades; os problemas são 
temporariamente resolvidos, contudo, dada a velocidade do aumento do comércio externo, são repostos novamente num nível de complexidade ainda maior. Novamente os investimentos estão sob responsabilidade da iniciativa privada (operadoras portuárias), que esperam pelos recursos financeiros públicos para executar as obras mais urgentes.

\section{Conclusão}

Numa perspectiva da longa duração, observando o movimento lento, secular dos portos no Brasil desde o início do século XIX, são perceptíveis dois movimentos caminhando paralelos. O primeiro é que no sistema portuário brasileiro a oferta sempre andou a reboque da demanda, ou seja, os investimentos feitos nos portos (melhoramento, reaparelhamento e modernização) sempre foram insuficientes para atender ao volume crescente do comércio externo brasileiro. Os investimentos rapidamente maturavam-se seguindo para um estrangulamento, exigindo mais e novos investimentos, porém, mais complexos e caros do que o anterior. Como a demanda anda à frente, o problema do estrangulamento é constantemente reposto num nível mais complexo. O segundo movimento é que, mesmo ao lado dos constantes estrangulamentos, foi se formando no Brasil um sistema portuário nacional integrado. Esse sistema acompanhou e contribuiu na formação do sistema nacional de economia. Rodovias, energia, telefonia, siderurgia, sistema de crédito e portos estão todos integrados e formam um sistema nacional de economia.

Também podemos observar três movimentos de média duração. $\mathrm{O}$ primeiro, que abrange todo o período imperial e início da República, foi caracterizado pela espera dos investimentos privados, com base nas leis de 1869 e 1886. O segundo, que veio após 1930, em que o Estado assumiu o processo de condução dos investimentos nos portos. E o terceiro é o atual, pós-1990, quando volta a crença no privado. Entre esses períodos mais definidos, podemos observar dois curtos momentos de transição. O primeiro foi nos anos de 1920, quando começavam a se alargar as funções do Estado, principalmente com as concessões feitas às unidades federativas, preparando-se para o período posterior de maior estatização. E o segundo foi nos anos 1980, quando, ao contrário da transição

anterior, o Estado começou a abandonar certas funções consideradas essenciais para a economia.

\section{Referências bibliográficas}

ALMEIDA, Silvia Guimarães de. A privatização no setor de transportes: o caso das concessões rodoviárias. Criciúma: Unesc, 2005.

AURELIANO, Liana Maria. No limiar da industrialização. São Paulo: Brasiliense, 1981. 
BARAT, Josef. O setor de transporte na economia brasileira. Revista de Administração Pública, Rio de Janeiro, v. 7, n. 4, out./dez. 1973.

. O setor de transportes. In: AFFONSO, Rui de B. A.; SILVA, Pedro L. (Org.). Federalismo no Brasil: empresas estatais e federação. São Paulo: Fundap, 1996.

BNDES. O BNDES e o Plano de Metas. Rio de Janeiro: BNDES, 1996.

CANO, Wilson. Raízes da concentração industrial em São Paulo. São Paulo: Hucitec, 1990.

CARDOSO DE MELLO, João Manuel. $O$ capitalismo tardio: contribuição à revisão crítica da formação e do desenvolvimento da economia brasileira. São Paulo: Brasiliense, 1988.

CONSELHO NACIONAL DE TRANSPORTES. Planos de viação: evolução histórica 1808-1973. Brasília: Ministério dos Transportes, 1974.

DRAIBE, Sônia Miriam. Rumos e metamorfoses: um estudo sobre a constituição do Estado e as alternativas da industrialização no Brasil 1930-1960. Rio de Janeiro: Paz e Terra, 1985.

GÓES, Hidelbrando Araújo. Problemas Portuários. Rio de Janeiro: Inspetoria de Porto, Rio e Canais, 1930.

LESSA, Carlos. Quinze anos de política econômica. São Paulo: Brasiliense, 1982.

LISBOA, Alfredo. Portos do Brasil. Rio de Janeiro: O Norte, 1922.

MATOS, Odilon Nogueira de. Vias de comunicações. In: HOLANDA, Sergio Buarque (Org.). História geral da civilização brasileira. Rio de Janeiro: Bertand do Brasil, 1995. v. II, n. 4.

MELLO, Carlos Theófilo de Souza. Sistema integrado de portos. Brasília, 1974.

PEIXOTO, João Baptista. Os transportes no atual desenvolvimento do Brasil. Rio de Janeiro: Editora Biblioteca do Exército, 1977.

PRADO JÚNIOR, Caio. Formação do Brasil contemporâneo. São Paulo: Brasiliense, 1996.

SIMONSEN, Roberto C. História econômica do Brasil (1500/1820). Brasília: Editora Nacional, 1977.

SUZIGAN, Wilson. Indústria brasileira: origem e desenvolvimento. Campinas; São Paulo: Editora da Unicamp; Hucitec, 2000.

\section{Mensagens presidenciais}

Disponíveis em $<$ http://wwwcrl.uchicago.edu $>$. Acesso em: 15 ago. 2004.

BRASIL. Mensagem apresentada ao Congresso Nacional pelo Presidente da República Francisco de Paula Rodrigues Alves. Rio de Janeiro: Imprensa Nacional, 1903. . Mensagem apresentada ao Congresso Nacional pelo Presidente da República

Wenceslau Braz Pereira Gomes. Rio de Janeiro: Imprensa Nacional, 1916. 
BRASIL. Mensagem apresentada ao Congresso Nacional pelo Presidente da República Wenceslau Braz Pereira Gomes. Rio de Janeiro: Imprensa Nacional, 1917.

- Mensagem apresentada ao Congresso Nacional pelo Presidente da República Arthur da Silva Bernardes. Rio de Janeiro: Imprensa Nacional, 1923.

Mensagem do Chefe do Governo Provisório Getúlio Vargas lida perante a Assembléia Nacional Constituinte, no ato da sua instalação, em 15 de novembro de 1933. Rio de Janeiro: Imprensa Nacional, 1933.

- Mensagem apresentada ao Congresso Nacional na Abertura da Sessão Legislativa em 1950 pelo Presidente da República Eurico Gaspar Dutra. Rio de Janeiro: Imprensa Nacional, 1950.

- Mensagem apresentada ao Congresso Nacional pelo Presidente da República Getúlio Vargas na Abertura da Sessão Legislativa de 1952. Rio de Janeiro: Imprensa Nacional, 1952.

- Mensagem apresentada ao Congresso Nacional pelo Presidente da República Juscelino Kubitschek na abertura da sessão legislativa de 1956. Rio de Janeiro: Imprensa Nacional, 1956.

- Mensagem apresentada ao Congresso Nacional pelo Presidente da República Juscelino Kubitschek na abertura da sessão legislativa de 1958. Rio de Janeiro: Imprensa Nacional, 1958.

. Mensagem apresentada ao Congresso Nacional pelo Presidente da República Juscelino Kubitschek na abertura da sessão legislativa de 1959. Rio de Janeiro: Imprensa Nacional, 1959.

Mensagem apresentada ao Congresso Nacional pelo Presidente da República João Goulart. Brasília: Imprensa Nacional, 1963.

Mensagem apresentada ao Congresso Nacional pelo Presidente Arthur da Costa e Silva em 1968. Brasília: Imprensa Nacional, 1968.

. Mensagem ao Congresso Nacional enviada pelo Presidente José Sarney. Brasília: Imprensa Nacional, 1989.

Mensagem ao Congresso Nacional enviada pelo Presidente José Sarney. Brasília: Imprensa Nacional, 1990.

\section{Relatórios}

BRASIL. Relatório apresentado ao Presidente da República dos Estados Unidos do Brasil pelo Ministro de Estado da Viação e Obras Públicas José Barbosa Gonçalves. Rio de Janeiro: Imprensa Nacional, 1912.

BRASIL. Relatório apresentado ao Presidente da República dos Estados Unidos do Brasil pelo Ministro de Estado da Viação e Obras Públicas Augusto Tavares de Lyra. Rio de Janeiro: Imprensa Nacional, 1917.

Relatório apresentado ao Presidente da República dos Estados Unidos do

Brasil pelo Ministro de Estado da Viação e Obras Públicas José Pires do Rio no ano de 1918. Rio de Janeiro: Imprensa Nacional, 1920. 
BRASIL. Relatório apresentado ao Presidente da República pelo Ministro da Viação e Obras Públicas Francisco Sá no ano de 1922. Rio de Janeiro: Imprensa Nacional, 1924.

Relatório apresentado ao Presidente da República pelo Ministro da Viação e Obras Públicas Victor Konder no ano de 1926. Rio de Janeiro: Imprensa Nacional, 1928.

. Relatório do Ministério da Viação e Obras Públicas apresentado pelo Ministro Ernani do Amaral Peixoto no ano de 1959. Rio de Janeiro: Serviço de Documentação, 1960.

MINISTÉRIO DA VIAÇÃO E OBRAS PÚBLICAS. Relatório dos Serviços Executados pelo Departamento Nacional de Portos e Navegação no ano de 1936 apresentado pelo Engenheiro Frederico Cezar Burlamaqui ao Ministro da Viação e Obras Públicas. Rio de Janeiro: DNPN, 1937a.

. Relatório dos Serviços Executados pelo Departamento Nacional de Portos e Navegação no ano de 1937 apresentado pelo Engenheiro Frederico Cezar Burlamaqui ao Ministro da Viação e Obras Públicas. Rio de Janeiro: DNPN, 1937b.

. Relatório dos Serviços Executados do Departamento Nacional de Portos, Rios e Canais em 1945 apresentado ao Ministro da Viação e Obras Públicas pelo Diretor Geral Clovis de Macedo Cortes. Rio de Janeiro: Imprensa Nacional, 1949.

Relatórios de Atividades do Departamento Nacional de Portos e Vias Navegáveis 1965. Rio de Janeiro: MVOP, 1965.

\section{Planos e outros}

BRASIL. Prodest - Programa de Desenvolvimento do Setor de Transportes 1986-1989. Brasília: Ministério dos Transportes, 1986a.

$1986 b$. I Plano Nacional de Desenvolvimento da Nova República 1986-1989. Brasília: . II Plano Nacional de Desenvolvimento (1975/1979). Brasília, 1975.

DEPARTAMENTO NACIONAL DE PORTOS E VIAS NAVEGÁVEIS. Informativo do Departamento Nacional de Portos e Vias Navegáveis, Ano V, n. 25, mar./abr. 1969.

GRUPO EXECUTIVO DE INTEGRAÇÃO DA POLÍTICA DE TRANSPORTES. Estudos de transportes do Brasil. Rio de Janeiro: Coverdale \& Colpitts, 1967. v. 1.

MINISTÉRIO DOS TRANSPORTES. Plano Diretor Portuário do Brasil: programa decenal de reaparelhamento e expansão dos portos para os períodos 1975-1984. Brasília: DNPVN; GEIPOT, 1974.

. Plano de desenvolvimento portuário 1987-1996. Brasília: Portobrás, 1986.

\section{Leis e decretos}

Disponíveis em: $<$ http://www2.camara.gov.br/legislacao/publicacao/doimperio $>$. Acesso em: 20 ago. 2004.

BRASIL. Decreto de 13 de julho de 1820. Coleção das Leis do Império do Brasil. Rio de Janeiro: Tipografia Nacional, 1889.

. Decreto n. 358 de 14 de agosto de 1845. Coleção das Leis do Império do Brasil de 1845. Rio de Janeiro: Tipografia Nacional, 1845. 
Alcides Goularti Filho

BRASIL. Decreto n. 447 de 19 de agosto de 1846. Coleção das Leis do Império do Brasil de 1846. Rio de Janeiro: Tipografia Nacional, 1847.

Decreto n. 1.746 de 13 de outubro de 1869. Coleção das Leis do Império do Brasil de 1869. Rio de Janeiro: Tipografia Nacional, 1869.

Lei n. 3.314 de 16 de outubro de 1886. Coleção das Leis do Império do Brasil de 1886. Rio de Janeiro: Imprensa Nacional, 1869.

Disponíveis em: $<$ http://www.senado.gov.br/servlets $>$. Acesso em: 18 ago. 2004.

Decreto n. 4.859 de 8 de junho de 1903.

. Decreto n. 6.368 de 14 de fevereiro de 1907.

. Decreto n. 24.497 de 29 de junho de 1934.

. Decreto n. 30.334 de 21 de dezembro de 1951.

Decreto $n .44 .203$ de 30 de julho de 1958.

. Decreto n. 46.434 de 15 de julho de 1959.

. Decreto $n .48 .524$ de 14 de julho de 1960.

Decreto n. 57.003 de 11 de outubro de 1965.

. Decreto n. 64.312 de 07 de abril de 1969.

. Decreto n. 76.925 de 29 de dezembro de 1975.

Decreto n. 4.122 de 13 de fevereiro de 2002.

. Decreto-Lei n. 1.058 de 19 de janeiro de 1939.

Decreto-Lei n. 6.145 de 29 de dezembro de 1943.

. Decreto-Lei n. 6.166 de 31 de dezembro de 1943.

. Decreto-Lei n. 7.995 de 24 de setembro de 1945.

. Decreto-Lei n. 794 de 27 de agosto de 1969.

Lei $n .652$ de 23 de novembro de 1899.

Lei n. 2.356 de 31 de dezembro de 1910.

. Lei n. 4.783 de 31 de dezembro de 1923.

. Lei n. 4.592 de 29 de dezembro de 1964.

. Lei n. 5.917 de 10 de setembro de 1973.

Lei n. 6.222 de 10 de julho de 1975.

Lei $n .8 .630$ de 25 de fevereiro de 1993.

Lei n. 10.233 de 05 de junho de 2001.

. Medida Provisória n. 151 de 15 de março de 1990. 


\section{Anexo}

Quadro 1A

Evolução dos órgãos responsáveis pelos portos

\begin{tabular}{|c|c|c|c|}
\hline Ministério Responsável & Órgãos responsáveis pelos portos & Período & Regime \\
\hline Marinha & Intendência dos Arsenais da Marinha & $1820-1845$ & Unidades isoladas \\
\hline Marinha & Capitania dos Portos & $1845-1873$ & Unidades isoladas \\
\hline $\begin{array}{l}\text { Agricultura, Comércio } \\
\text { e Obras Públicas }\end{array}$ & & $1873-1890$ & Unidades isoladas \\
\hline $\begin{array}{l}\text { Agricultura, Comércio } \\
\text { e Obras Públicas }\end{array}$ & Inspetoria de Distritos & $1890-1910$ & Unidades isoladas \\
\hline $\begin{array}{l}\text { Viação e Obras } \\
\text { Públicas }\end{array}$ & Inspetoria Federal de Portos, Rios e Canais & $1910-1934$ & Departamento \\
\hline $\begin{array}{l}\text { Viação e Obras } \\
\text { Públicas }\end{array}$ & $\begin{array}{l}\text { Departamento Nacional de Portos e } \\
\text { Navegação }\end{array}$ & 1934-1943 & Departamento \\
\hline $\begin{array}{l}\text { Viação e Obras } \\
\text { Públicas }\end{array}$ & $\begin{array}{l}\text { Departamento Nacional de Portos, Rios e } \\
\text { Canais }\end{array}$ & $1943-1963$ & Departamento \\
\hline Transportes & $\begin{array}{l}\text { Departamento Nacional de Portos e Vias } \\
\text { Navegáveis }\end{array}$ & $1963-1975$ & Autarquia \\
\hline Transportes & Portobrás S.A. & $1975-1990$ & Empresa Holding \\
\hline Infra-estrutura & Departamento de Portos & $1990-1993$ & Departamento \\
\hline Transportes & $\begin{array}{l}\text { Departamento Nacional de Transportes } \\
\text { Aquaviários }\end{array}$ & $1993-2001$ & Departamento \\
\hline Transportes & $\begin{array}{l}\text { Agência Nacional de Transportes } \\
\text { Aquáticos }\end{array}$ & 2001 & $\begin{array}{l}\text { Agência } \\
\text { Reguladora }\end{array}$ \\
\hline
\end{tabular}

Fonte: Relatório do Ministério da Marinha; Ministério da Agricultura, Comércio e Obras Públicas; Ministério da Viação e Obras Públicas; Ministério dos Transportes; Mensagens Presidenciais; Relatórios do IFPRC, DNPN, DNPRC, DNPVN, Portobrás, Antaq.

Quadro 2A

Regime jurídico dos portos brasileiros

\begin{tabular}{|l|c|c|}
\hline Decreto/Lei & Data & Características \\
\hline Decreto n. 1.746 & $13 / 10 / 1869$ & $\begin{array}{r}\text { Concessão à iniciativa privada por 90 anos e garantia de juros de 12\% } \\
\text { ao ano }\end{array}$ \\
\hline Lei n. 3.314 & $16 / 10 / 1886$ & $\begin{array}{r}\text { Concessão à iniciativa privada por 70 anos, garantia de juros de 6\% ao } \\
\text { ano e taxa de 2\% sobre importações e 1\% sobre exportações }\end{array}$ \\
\hline Decreto n. 4.859 & $08 / 06 / 1903$ & $\begin{array}{r}\text { Construção feita pelo Estado repassando a administração à iniciativa } \\
\text { privada por 10 anos e criação da caixa especial }\end{array}$ \\
\hline Decreto n. 24.599 & $06 / 07 / 1934$ & $\begin{array}{r}\text { Autoriza o governo federal a contratar o melhoramento e a exploração } \\
\text { comercial dos portos aos Estados ou a entidades privadas }\end{array}$ \\
\hline Decreto n. 749 & $27 / 08 / 1969$ & $\begin{array}{c}\text { Autoriza a União a formar sociedade de economia mista ou empresa } \\
\text { pública destinada a explorar os portos, terminais e vias navegáveis }\end{array}$ \\
\hline Lei n. 8.630 & $25 / 02 / 1993$ & \begin{tabular}{c} 
Privatização das operações portuárias e quebra da estrutura sindical \\
\hline
\end{tabular} \\
\hline
\end{tabular}

Fonte: Respectivos Decretos e Leis. 
Quadro 2A

Concessão e encampação dos portos brasileiros

\begin{tabular}{|c|c|c|c|}
\hline Porto & $\begin{array}{c}\text { Ano da } \\
\text { concessão }\end{array}$ & Empresa & $\begin{array}{l}\text { Ano de } \\
\text { encampação e da } \\
\text { nova concessão }\end{array}$ \\
\hline Porto da Bahia & 1871 & $\begin{array}{c}\text { Francisco Ignácio Ferreira e Manoel Jesuíno } \\
\text { Ferreira }\end{array}$ & 1887 \\
\hline Porto da Bahia & 1891 & $\begin{array}{c}\text { Frederico Merei e Augusto Candido Harache } \\
\text { (Companhia Docas e Melhoramentos da } \\
\text { Bahia) }\end{array}$ & 1970 \\
\hline Porto de Santos & 1870 & $\begin{array}{l}\text { Conde da Estrela e Francisco Praxedes de } \\
\text { Andrade }\end{array}$ & 1886 \\
\hline Porto de Santos & 1888 & $\begin{array}{c}\text { José Pinto de Oliveira, Cândido Gaffrée e } \\
\text { Eduardo Palassin Guinle (Gaffrée, Guinle e } \\
\text { Cia. Docas de Santos) }\end{array}$ & 1980 \\
\hline Porto de Pernambuco & 1889 & $\begin{array}{c}\text { José da Silva Loyo Júnior e Antônio João de } \\
\text { Amorim }\end{array}$ & 1891 \\
\hline Porto de Pernambuco & 1891 & Empresa de Obras Públicas do Brasil & 1895 \\
\hline Porto de Pernambuco & 1895 & Edmond Bartissol e Deméytrio Nunes Ribeiro & 1909 \\
\hline Porto de Pernambuco & 1909 & $\begin{array}{l}\text { Société de Construction du Port de } \\
\text { Pernambuco }\end{array}$ & 1918 \\
\hline Porto de Ceará & 1883 & $\begin{array}{c}\text { Tobias Luriano Figueira de Mello e Ricardo } \\
\text { Lange } \\
\text { (Caerá Harbour Corporation) }\end{array}$ & 1898 \\
\hline Porto de São Luiz & 1890 & $\begin{array}{c}\text { Companhia Geral de Melhoramento do } \\
\text { Maranhão }\end{array}$ & 1925 \\
\hline Porto de Laguna/SC & 1890 & $\begin{array}{c}\text { Companhia Industrial e de Construções } \\
\text { Hidráulicas }\end{array}$ & 1904 \\
\hline Porto de Vitória & 1892 & Companhia Brasileira de Torrens & 1906 \\
\hline Porto de Vitória & 1906 & Companhia Porto de Vitória & 1924 \\
\hline Porto de Jaraguá/AL & 1894 & $\begin{array}{c}\text { Companhia Industrial e de Construções } \\
\text { Hidráulicas }\end{array}$ & 1896 \\
\hline Porto de Jaraguá/AL & 1896 & The National Brazilian Harbour Comp & 1905 \\
\hline Porto do Pará & Janeiro/1902 & João Augusto Cavallero e Frederico Bender & Dezembro/1902 \\
\hline Porto do Pará & 1902 & Percival Farquhar (Port of Pará) & 1940 \\
\hline Porto de Manaus & 1900 & B. Rymkiewicz \& Co. & 1902 \\
\hline Porto de Manaus & 1902 & Companhia Manaos Harbour Limited & 1967 \\
\hline $\begin{array}{l}\text { Porto de Rio } \\
\text { Grande/RS }\end{array}$ & 1906 & Compagnie Française du Rio Grande do Sul & 1918 \\
\hline Porto de Natal & 1922 & C. H. Walker \& Co. & 1927 \\
\hline Porto de Ilhéus & 1923 & $\begin{array}{c}\text { Bento Berillo de Oliveira } \\
\text { (Companhia Industrial de Ilhéus) }\end{array}$ & 1963 \\
\hline
\end{tabular}

Fonte: Decretos federais de autorização, concessão, rescisão e encampação dos respectivos portos. 
Melhoramentos, reaparelhamentos e modernização dos portos brasileiros: a longa e constante espera

Quadro 3A

Investimentos realizados pelo DNPVN, Portobrás e Departamento de Portos 1962-1994

\begin{tabular}{|c|c|c|c|c|c|}
\hline \multicolumn{2}{|c|}{ DNPVN } & \multicolumn{2}{|c|}{ Portobrás } & \multicolumn{2}{|c|}{ Departamento de Portos } \\
\hline Ano & US\$ milhões & Ano & US\$ milhões & Ano & US\$ milhões \\
\hline 1963 & 50,3 & 1976 & 191,7 & 1990 & 16,0 \\
\hline 1964 & 46,9 & 1977 & 191,5 & 1991 & 31,2 \\
\hline 1965 & 42,8 & 1978 & 259,8 & 1992 & 27,5 \\
\hline 1966 & 69,3 & 1979 & 135,8 & 1993 & 31,6 \\
\hline 1967 & 61,7 & 1980 & 211,4 & 1994 & 8,7 \\
\hline 1968 & 103,8 & 1981 & 146,5 & & \\
\hline 1969 & 43,4 & 1982 & 170,8 & & \\
\hline 1970 & 29,4 & 1983 & 70,4 & & \\
\hline 1971 & 65,8 & 1984 & 60,7 & & \\
\hline 1972 & 104,1 & 1985 & 59,4 & & \\
\hline 1973 & 151,1 & 1986 & 90,9 & & \\
\hline 1974 & 123,4 & 1987 & 74,6 & & \\
\hline \multirow[t]{2}{*}{1975} & 151,8 & 1988 & 48,6 & & \\
\hline & & 1989 & 11,9 & & \\
\hline
\end{tabular}

Fonte: Para os anos 1963-1988, ver Barat (1996). Para os anos 1989-1994, ver Almeida (2005). 